\title{
Depreciation, income distribution and the UK REIT
}

Article

Accepted Version

Baum, A. and Devaney, S. (2008) Depreciation, income distribution and the UK REIT. Journal of Property Investment and Finance, 26 (3). pp. 195-209. ISSN 1463-578X doi: https://doi.org/10.1108/14635780810871597 Available at https://centaur.reading.ac.uk/19800/

It is advisable to refer to the publisher's version if you intend to cite from the work. See Guidance on citing.

To link to this article DOI: http://dx.doi.org/10.1108/14635780810871597

Publisher: Emerald Group Publishing Limited

All outputs in CentAUR are protected by Intellectual Property Rights law, including copyright law. Copyright and IPR is retained by the creators or other copyright holders. Terms and conditions for use of this material are defined in the End User Agreement.

\section{www.reading.ac.uk/centaur}

\section{CentAUR}

Central Archive at the University of Reading

Reading's research outputs online 


\title{
Depreciation, Income Distribution and the UK REIT
}

\author{
Andrew Baum ${ }^{\#}$ and Steven Devaney* \\ \#Department of Real Estate and Planning \\ Whiteknights, Reading, \\ RG6 6AW, UK \\ * University of Aberdeen Business School \\ Edward Wright Building, Dunbar Street, \\ Aberdeen, AB24 3QY, UK
}

Published in 2008 in the Journal of Property Investment and Finance, Vol. 26, Issue 3, Pages 195-209

DOI: http://dx.doi.org/10.1108/14635780810871597

Current details for contact author (updated 2015):

Dr Steven Devaney, Real Estate \& Planning, Henley Business School, University of Reading, READING, RG6 6UD, UK. Email: s.devaney@henley.reading.ac.uk

Acknowledgements: This paper originated from a larger project on depreciation (IPF, 2005a) that was commissioned and funded under the auspices of the IPF Educational Trust and IPF Joint Research Programme. We are grateful for the support of the IPF and IPF Educational Trust, and for the permission to reproduce empirical results first presented there. 


\begin{abstract}
Purpose - The paper considers prospects for UK REITs, which were introduced on 1st January 2007. It specifically focuses on the potential influence of depreciation and expenditure on income and distributions.
\end{abstract}

Methodology I Approach - First, the ways in which depreciation can affect vehicle earnings and value are discussed. This is then set in the context of the specific rules and features of REITs. An analysis using property income and expenditure data from Investment Property Databank (IPD) then assesses what gross and net income for a UK REIT might have been like for the period 1984-2003.

Findings - A UK REIT must distribute at least $90 \%$ of net income from its property rental business. Expenditure, therefore, plays a significant part in determining what funds remain for distribution. Over 1984-2003, expenditure has absorbed $20 \%$ of gross income and been a source of earnings volatility, which would have been exacerbated by gearing.

Implications - Expenditure must take place to help UK REITs maintain and renew their real estate portfolios. In view of this, investors should moderate expectations of a high and stable income return, although it may well still be so relative to alternative investments. 
Originality I value - Previous literature on depreciation has not quantified amounts spent on portfolios to keep depreciation at those rates. Nor, to our knowledge, has its ideas been placed in the indirect investor context.

Keywords - depreciation, capital expenditure, income distribution, UK REITs

Paper type - Research paper 


\section{Introduction}

Over the last three years, there has been serious debate regarding the introduction of a quoted tax-transparent real estate investment vehicle into the UK. This has culminated in the passing of legislation in the Finance Act 2006 that enables real estate investment companies to convert to tax transparent status provided they meet certain rules. The new vehicles will be known as UK REITs. It has been argued that the introduction of UK REITs will increase investment in property (particularly by small investors), encourage regeneration, facilitate the supply of housing and enable assets currently held offshore for tax reasons to be brought back within the UK regulatory system (BPF/IPF/RICS, 2004a). Whether any of these ambitions can be realised depends on the structure of the new vehicles and the success of their launch.

Long established examples of tax transparent vehicles exist in the shape of Real Estate Investment Trusts (REITs) in the United States and the Australian Listed Property Trusts (LPTs). However, it was proposals for such vehicles in other European countries that helped accelerate the debate in the UK. In particular, the successful introduction in 2003 of Societes d'Investissements Immobiliers Cotees (SIICs) in France led to arguments in the UK about the need to maintain national competitiveness. Official proposals soon followed, with the Treasury publishing a consultation document in March 2004 (HM Treasury, 2004) and a proposed framework for a tax transparent vehicle in the 2005 Budget (HM Treasury, 2005). Each of these invited feedback from the real estate industry and this subsequently helped shape the 2006 legislation, which enables UK REITs to appear for accounting periods beginning on or after $1^{\text {st }}$ January 2007. 
The UK REIT structure should provide investors with returns that are closer to those of the direct property market in comparison with shares in current UK listed companies. This is because of the obligation on UK REITs to pay out a high proportion of taxable income, the removal by government of 'double taxation' on that income and other rules about their activities and investments. Therefore, it is likely that they will be popular with investors, especially in the case of commercial real estate, which in recent years has seen a rising volume of direct investment and the launch of many new unlisted products. In particular, it is perceived that commercial real estate offers investors a stable and relatively high income return, as well as having other advantages such as its role in portfolio diversification (IPF, 2005b).

However, it is also well recognised that property investments depreciate in value through time and require expenditure to maintain their condition and income earning potential. The argument of this paper is that these costs may be higher than generally appreciated, because significant expenditure is required to maintain and renew real estate portfolios. For indirect investors, this is important because UK REIT distributions are set at a high proportion of net income, i.e. income after property related expenditure and other costs such as debt interest. Hence, high and stable rental cash flows may not translate into a high and stable dividend income stream. This proposition is tested empirically within the paper.

The rest of the paper is organised as follows. First, it discusses how depreciation affects properties and is thus able to impact on the earnings and value of property investment vehicles. The paper then sets out the specific context of the UK REIT. Following this, the experience of US REITs with respect to expenditure and distributions is examined, but 
differences between US and UK accounting regimes and markets mean that the main analysis is of historic cash flow data for UK portfolios. The implications of depreciation and expenditure for UK REIT investors are then summarised in the conclusion.

\section{The Effects of Depreciation}

Depreciation can affect the performance and value of real estate vehicles in a number of ways. This section sets out how it affects commercial real estate directly and then considers how, in turn, depreciation influences real estate vehicle performance and management.

\section{Depreciation and Direct Property Investment}

In the context of real estate, depreciation has been defined by Law (2004) as follows:

"the rate of decline in rental [capital] value of an asset (or group of assets) over time relative to the asset (or group of assets) valued as new with contemporary specification" (Law, 2004: 242).

This definition relates to the economic depreciation of assets, with which this paper is primarily concerned. This is distinct from depreciation as used in corporate accounting; a method of reducing the book value of assets through time to reflect in company profits the consumption of capital assets that will need to be replaced. In the case of the UK, such methods have not been allowed for properties held as investments, which must be shown in accounts at market value [1]. 
Whilst this clarifies the concept underlying the discussions that follow, the definition does not indicate the causes of such depreciation, which it is helpful to briefly consider. In particular, Baum (1991) sets out following causes of depreciation in commercial property values:

- Physical deterioration: this relates to the wearing out of the building through time.

- Building obsolescence: this refers to changes in what is expected from buildings, the most obvious source of which are changes in technology that impact upon occupier requirements and may render a building's design or configuration redundant.

- Site value changes: these result from changes in planning, the local environment and supply and demand within sub-markets [2]. Technically, they are excluded under the definition of depreciation given above, but they also impact upon values and are, in practice, extremely difficult to exclude from any measurement of depreciation.

These factors can affect rental values and capital values, as they will influence the rent that a potential tenant would be prepared to pay and they will have consequences for future cashflows either in the form of reduced rents and/or capital expenditure in order to combat their effects.

Several studies have attempted to measure the impact of depreciation on property values. Those conducted for the UK commercial real estate market include CALUS (1986), Baum (1991, 1997), JLW (1987), Barras and Clark (1996) and CEM (1999). The 
results of these studies are summarised in IPF (2005a), which itself also conducts a measurement exercise. Whilst the rates found are interesting, IPF (2005a) noted that all of these results were measured after the effects of expenditure. In other words, they display a 'net' rate, which does not reflect the efforts by investors to restrict depreciation to that rate. The full cost of depreciation includes expenditure needed to maintain and renew the properties in a portfolio. Later in this paper, expenditure is examined in detail so that the effects of depreciation on the income and distributions of UK REITs can be better understood.

\section{Depreciation and Indirect Property Investment}

Rental depreciation creates the most basic effect on vehicle performance by reducing income received from properties through time. This can be through falls in property rental values or through slower rental growth compared to benchmarks, which may make a vehicle perform less well than its competitors. Depending on the country and sector, lease structures may be able to protect investors from rental depreciation to some extent, but eventually property rents will need to adjust either at rent reviews or reletting. The implications are that unless rental depreciation is tackled through renewal of the property or portfolio, earnings growth will be affected, with knock-on impacts on dividends and equity valuation.

Addressing rental depreciation is likely to require expenditure on properties. A certain amount of spending may be needed before a building can be re-let, while other repairs and improvements can be important in maintaining or improving rental value, particularly in the context of competition from other properties and schemes. This spending will have an effect on dividends too, as income will be reduced. However, it is worth noting that 
the consequence for future earnings and dividends of not undertaking expenditure could be greater than the present cost.

Both rental depreciation and expenditure requirements influence the yields and capital values of vehicle assets. For instance, where depreciation is being caused by functional obsolescence, it may make a building of less or no value to occupiers now (reducing ERV), require expenditure in order to put right (reducing future income) and mean that future cash flows are more uncertain (causing the yield to rise, as the property is more risky). This will then feed through into company net asset value (NAV). It will also affect vehicle share price, irrespective of whether prices are related directly to NAV, as is the case for current UK quoted property companies, or to the future expected cash flows of the firm, as is the case for US REITS.

So these relatively simple property level effects can have far-reaching implications for the vehicles that own properties and the investors holding the shares or units. The size of the impact will depend on many factors: the size of the vehicle, the nature of the properties it owns, the particular causes of depreciation at any one time and a vehicle's structure and flexibility to deal with such risks. This last point is particularly significant for tax transparent vehicles, where distribution rules may constrain expenditure to combat depreciation or where other restrictions may prevent declining properties from being redeveloped or traded out of the portfolio. Current and future earnings can be affected, as well as the realisable value of the asset base.

\section{UK Rules on Income Distribution}


In considering the possible impact of depreciation on UK REITs, it is now important to set out the rules under which they must operate. These include requirements to:

1. Be a "property rental business", with $75 \%$ of income arising from that business and $75 \%$ of assets dedicated to it (Finance Act, s 108). However, as long as these tests are satisfied, a UK REIT may carry out taxable ancillary activities, which can include property (re-)development.

2. Distribute at least $90 \%$ of the profits of the property rental business (Finance Act, s 107). This does not include capital gains from selling property, though, which can either be distributed or re-invested in the portfolio (Finance Act, s 118).

The qualifications to each requirement are important, as they appear to give UK REITs flexibility to manage depreciation and renew their portfolios. Also important is the fact that distributions will be from profits rather than gross income. It had been initially suggested by government that UK REITs should distribute at least $90 \%$ of income "before depreciation" (HM Treasury, 2004: 21), but this was later recognised as unsuitably high, with $95 \%$ and then $90 \%$ of profits proposed instead. While these steps have, on the face of it, reduced the level of dividends to investors, they were critical for the proper management of assets. Otherwise, UK REITs could have been left with insufficient cash to maintain properties and thus forced to defer expenditure, sell assets or make regular capital issues (BPF/IPF/RICS, 2004b; Lizieri, 2004), with potentially serious impacts on vehicle performance and success. 
The rules address concerns raised during the consultation process about the ability of the UK REIT to manage depreciation. However, questions remain about what the effect of depreciation on vehicle returns might be, particularly with regard to distributions. To answer these, a natural step would seem to be to explore the experiences of REIT structures in other countries, particularly those of the long-established US REIT. Hence, the paper now examines the US situation as a prelude to analysis of UK portfolio data, but, in doing so, it highlights a number of reasons why UK REITs will differ.

\section{Distributions - the US experience}

US REITs are one of the longest standing and most researched tax transparent vehicles in existence. There are a large number of articles in the academic literature relating to them, but it should be noted that much of this literature is focused on topics such as performance, diversification and the nature of returns - to what extent US REITs are real estate and to what extent stocks (see reviews of the literature in Corgel et al, 1995 and Worzala and Sirmans, 2003). Structural aspects, such as distribution rules, receive less attention despite their influence on returns and investor attractiveness. However, there are some studies on US REIT distribution policy from which insights can be gained and which provide a link into the wider financial literature on dividends and earnings retention.

\section{REIT Income Distributions}

When Real Estate Investment Trusts were introduced in the US in 1960, a high compulsory income distribution level of $90 \%$ was set, later increased to $95 \%$. These 
distributions were to be made from net income after the deduction of expenses, interest and a depreciation allowance, recognising that:

- Real estate vehicles need the ability to retain some earnings through which reinvestment and renewal of the stock can be made.

- In a particular year, a real estate owner can be faced with significant costs to repair and maintain buildings for existing or prospective occupiers.

More recently, in the REIT Modernisation Act 1999, the compulsory distribution level was reduced back to $90 \%$ of net income. Yet the change did not appear to have a big impact on US REIT values, although Howe and Jain (2004) found positive share price reactions to the Act as a whole. The reason for this limited impact was that REIT dividends are only partially constrained by the minimum distribution requirement.

As noted by Campbell and Sirmans (2002), the average payout by US REITs is often over $100 \%$ of accounting earnings. In other words, not only are dividends paid in excess of the compulsory level, but some payouts are also above recorded net income. This is confirmed by the studies of Wang et al (1993) and Bradley et al (1998), with the former reporting an average payout ratio of 1.65 , where payout ratio is the ratio of dividends to reported net income. This was compared to an expected 0.95 if regulation were the only driver. Meanwhile, for 2003, IPF (2005a) reported a similar average payout ratio of 1.64 , whereas regulation alone would point to an average around 0.9.

The reason for these high proportions is that there is a big difference between reported net income and the net cash flow that an Equity (property owning) REIT has available to 
distribute. This difference is created by large provisions for depreciation and amortization, associated with a cost treatment of commercial real estate assets in accounts. Such provisions are not available to Mortgage REITs and data from IPF (2005a) shows that these have an average payout ratio of 0.91 , close to the statutory limit.

In the US REIT industry, it is recognised that the accounting measure of net income is thus not a useful measure of Equity REIT profitability (Yungmann and Taube, 2001). Therefore, other measures have been developed, such as Funds From Operations (FFO), Adjusted Funds From Operations (AFFO) and Funds Available for Distribution (FAD). While these different metrics offer alternative ways of assessing REIT earnings, there is a lack of consistency in how they are calculated between firms. In the absence of uniform measures, it becomes difficult to assess how much of the gross income from properties is required for US REITs to operate and how much can be paid out.

Furthermore, the difference between net income and net cash flow gives US REITS flexibility to pursue distribution policies, the reasons for and motivations behind which are not straightforward. For instance, Wang et al (1993) suggest several hypotheses to explain the high payout ratios observed and differences between the ratios of different firms. One strand of argument is rooted in agency cost theory and states that shareholders prefer managers to return cash flows rather than keep them within the company. Then, when future decisions have to be taken, such as whether to undertake a major refurbishment, managers must submit their proposals to the capital markets since there are no retained funds. Therefore, greater monitoring of management by the investors can take place. 
However, in examining differences between firms, Bradley et al (1998) argued that their results were inconsistent with agency explanations. They related dividend ratios and policies to the anticipated volatility in future cash flows, as proxied by variables such as firm size, gearing and portfolio diversification. Firms with higher volatility might be expected to have higher agency costs and thus pay out more than other firms, but this was found not to be the case. The alternative explanation put forward by the authors was that dividends are used to convey information about expected earnings, with higher payouts signalling more confidence in future cash flows.

\section{Differences between UK and US}

Whether UK REITs will encounter a similar situation and be able to pursue such policies is a matter of interest, but it can be quickly shown that this is unlikely to be the case.

Earlier it was stated that UK REITs would be required to show their properties at market value in their accounts. Under such a regime, no allowance for depreciation is made to offset against taxable income; values change with market conditions rather than being written down each year. This difference from the US treatment means that the distributable profits of a UK REIT will be much closer to its cash flow and so there is no decision to be made about whether some or all of an allowance should be retained.

Even if accounting differences were not a factor, other differences between the countries exist that may influence distribution and retention decisions. In particular, a key difference lies in the nature of the leases granted in each country. The terms and conditions of leases granted will determine whether the REIT or the tenant is responsible 
for repairs and maintenance. This, in turn, not only influences the pattern of income and expenditure, but potentially also the extent and amount of depreciation in the portfolio (Baum and Turner, 2004).

For many years, the following lease terms were typical for prime property space in the UK. Leases were agreed for long periods, often 25 years, with five year rent review intervals and upward-only rent reviews as standard. In addition, repairing and insuring costs were passed on to tenants through full repairing and insuring (FRI) clauses. Although, in recent years, leases have become shorter and opportunities to break have increased, these repairing and rent review provisions still predominate (Crosby et al, 2005). In the US, leases are shorter on average [3] and more of the repairing obligations are borne by the landlord.

This means that, in terms of tackling depreciation, there are more opportunities for the US owner to actively manage its buildings and more incentive to do so owing to the need to achieve re-lettings more often. In contrast, UK leases have tended towards more passive management of the stock. Responsibility for regular maintenance to combat physical deterioration is passed to the tenant, especially in single-let buildings, but there is no guarantee that the tenant will perform these obligations in the same way and, often, they are discharged through payment of a dilapidations charge at the end of the lease instead. While, in theory, this compensates the landlord for lost value, the impact of not performing work when necessary may mean greater depreciation and cost overall.

More important from the perspective of this paper are the implications that this has for income returns on the vehicle. The different lease terms mean differences in the nature 
of the income received (see Kennedy et al, 2004). In the US, there is a wide difference between the gross income received and the net operating incomes (NOI) from which distributions are made. In the UK, gross income and NOI are very close together. However, the restrictions on tackling depreciation caused by the UK lease structure may mean that this small difference between gross income and NOI is artificial, with income returns being higher than they should be at the expense of capital return in the short term. An alternative angle offered by Baum and Turner (2004) is that under the shorter and more flexible (in this case, US) leases, more reinvestment in the stock is taking place, which suggests better total returns in the long run, though this is very difficult to prove empirically at present.

Hence, the experiences of the US and indeed other jurisdictions are only of limited value when assessing the likely returns from the UK REIT because of both accounting and property market differences. Yet important insights can be drawn from the differences. In particular, a failure to appreciate leasing differences and their effects on income return could put a UK REIT at risk of over-distribution in the short term at the expense of its long-term capital value.

\section{Income from and Expenditure on UK Real Estate}

An alternative approach to exploring the impact of depreciation and property expenditure on distributable earnings is to look directly at the cash flows of UK property portfolios. In effect, the analysis examines the portfolio as if it had been that of a UK REIT operating over the period in question. 
As noted already, depreciation can affect portfolio income in two particular ways: it can influence income received through its effect on rental values and it can influence net income through its impact on expenditure to maintain and renew the asset base. Whilst several previous studies have tried to measure the influence of depreciation on values (especially rental values), neither of the above aspects has been explored directly in the property investment literature. In this analysis, both gross and net income through time for a held sample of properties is presented, where net income is net of expenditure, but before debt interest.

\section{Data and method}

The analysis draws on a dataset created for IPF (2005a) from the UK database of IPD, a commercial organisation that provides performance measurement and benchmarking services to real estate investors. It comprises of a sample of 624 properties that were held over the period 1984-2003 (19 years). The sample provides a long run of income and expenditure data and is spread across different property types and locations. It also includes buildings of different ages as at the start of the period and so simulates a diversified portfolio held for 19 years. The data relates to institutional grade property, since contributors to IPD in the UK are, predominantly, insurance companies, pension funds and publicly-listed property companies. However, it would be expected that UK REIT portfolios would be comprised of institutional grade property as well.

As the analysis refers to a held portfolio of properties, the potential influence of trading assets is not reflected. A vehicle may be able to improve its income and returns, and avoid large costs, by replacing and renewing its portfolio of properties. While this means 
that the possible benefit of new purchases does not show through in the figures above, this is counterbalanced by the fact that there are no retirements in the data either (buildings that may have had very bad performance, but which were sold out rather than held). Another potential feature is survivor bias, with the sample reflecting properties retained by their owners because of superior performance. This was tested in IPF (2005a: 50-52) and some out-performance relative to a control sample of properties was noted, being $1 \%$ per annum in terms of total returns.

For all properties in the sample, records are held on the amount of income received and the amount of regular expenditure paid out by owners, including the payment of property management fees, as well as the amounts of any irrecoverable capital expenditure that takes place. However, work undertaken by tenants in performance of lease obligations or costs that are reimbursed to the owner through dilapidations payments or service charges are not recorded. Whilst these do not affect the earnings of the owner, it does mean that the expenditure recorded probably understates the true running costs of the properties. In addition, if the practical consequences of such arrangements are that under-investment takes place in the long run, then any long term impacts on earnings will be masked.

Nonetheless, from these records, the gross and net income for the sample of properties can be calculated. The margin between the two can then be examined, giving investors an insight into how much of the income is likely to be required to meet the maintenance and refurbishment needs of a UK REIT portfolio. However, it must be borne in mind that, while expenditure may alleviate depreciation, it cannot eliminate it entirely. There is a well recorded difference between curable and incurable depreciation (Baum, 1994) and 
redevelopment or renewal of the stock may be required even if expenditure has been applied to the curable depreciation element.

For each year over the period 1984-2003, the total income for all the properties was computed, as well as two measures of net income. These were

"Net income" $\quad=\quad$ Total income - Revenue expenditure

"Net cash flow" $\quad=\quad$ Total income $-($ Revenue + capital expenditure $)$

Total income is mostly the rent receivable on the sample, although there are small amounts of other property related income and occasional instances of capital receipts, which have also been included. Expenditure is then divided between "revenue" and "capital" expenditure. It is classified as revenue expenditure if the spending by the owner is for the regular management of the properties. It is classed as capital expenditure where funds are for the refurbishment or improvement of the property.

IPD also record "development" expenditure, where cash flows would be entered if any property had been redeveloped. However, while the measurement sample contains refurbishments, redevelopments are not included. So the analysis reflects revenue and capital expenditure to combat curable depreciation, but not the complete replacement of buildings which may be needed to solve incurable factors. This also points to understatement of property/portfolio running costs and indicates that the net income figures calculated here should be taken as an upper bound, since, clearly, this redevelopment activity would impact earnings further. As it is based directly on property records, the analysis also excludes the impact of gearing. 


\section{Results}

The results of the income and expenditure investigation for all properties are shown in

Table I. Further results for the shop, office and industrial sectors of the UK commercial property market are then summarised in Table II, with full results presented in the appendix. Shops are considered rather 'All Retails' owing to the small number of assets in the Retail Warehouse and Shopping Centre segments that were held continuously over the period in question.

Table I - Income and expenditure for portfolio of 624 properties held over the period 19842003 (figures in millions)

\begin{tabular}{cccccccc}
\hline \multicolumn{2}{c}{$\begin{array}{c}\text { Total } \\
\text { income }\end{array}$} & $\begin{array}{l}\text { IPD defined } \\
\text { revenue } \\
\text { expenditure }\end{array}$ & $\begin{array}{l}\text { Net } \\
\text { income }\end{array}$ & $\begin{array}{l}\text { as \% of } \\
\text { gross } \\
\text { income }\end{array}$ & $\begin{array}{l}\text { IPD defined } \\
\text { capital } \\
\text { expenditure }\end{array}$ & $\begin{array}{l}\text { Net cash } \\
\text { flow }\end{array}$ & $\begin{array}{l}\text { as \% of } \\
\text { gross } \\
\text { income }\end{array}$ \\
\hline & & & & & & & \\
1984 & 91.3 & 7.5 & 83.7 & $92 \%$ & 12.7 & 71.1 & $78 \%$ \\
1985 & 98.4 & 7.0 & 91.5 & $93 \%$ & 17.3 & 74.2 & $75 \%$ \\
1986 & 103.4 & 6.6 & 96.8 & $94 \%$ & 12.2 & 84.6 & $82 \%$ \\
1987 & 117.1 & 7.0 & 110.1 & $94 \%$ & 13.9 & 96.3 & $82 \%$ \\
1988 & 131.5 & 7.8 & 123.7 & $94 \%$ & 19.1 & 104.6 & $80 \%$ \\
1989 & 155.1 & 10.1 & 145.0 & $93 \%$ & 47.4 & 97.6 & $63 \%$ \\
1990 & 181.7 & 14.1 & 167.5 & $92 \%$ & 12.9 & 154.7 & $85 \%$ \\
1991 & 208.7 & 18.4 & 190.2 & $91 \%$ & 15.4 & 174.8 & $84 \%$ \\
1992 & 216.6 & 22.0 & 194.6 & $90 \%$ & 8.2 & 186.4 & $86 \%$ \\
1993 & 226.9 & 25.7 & 201.2 & $89 \%$ & 7.6 & 193.6 & $85 \%$ \\
1994 & 227.4 & 23.5 & 203.9 & $90 \%$ & 29.2 & 174.7 & $77 \%$ \\
1995 & 224.4 & 23.9 & 200.5 & $89 \%$ & 41.0 & 159.5 & $71 \%$ \\
1996 & 232.3 & 22.3 & 210.0 & $90 \%$ & 36.5 & 173.5 & $75 \%$ \\
1997 & 242.9 & 21.4 & 221.4 & $91 \%$ & 13.4 & 208.0 & $86 \%$ \\
1998 & 236.0 & 23.6 & 212.5 & $90 \%$ & 14.1 & 198.4 & $84 \%$ \\
1999 & 243.1 & 21.2 & 221.9 & $91 \%$ & 28.5 & 193.4 & $80 \%$ \\
2000 & 250.4 & 19.8 & 230.6 & $92 \%$ & 33.3 & 197.3 & $79 \%$ \\
2001 & 268.7 & 21.5 & 247.1 & $92 \%$ & 36.6 & 210.6 & $78 \%$ \\
2002 & 280.7 & 25.9 & 254.8 & $91 \%$ & 25.0 & 229.8 & $82 \%$ \\
2003 & 287.6 & 25.9 & 261.7 & $91 \%$ & 17.5 & 244.2 & $85 \%$ \\
Average & & & & $91 \%$ & & & $80 \%$ \\
\hline
\end{tabular}


One of the most striking things about the figures in Table I is the rise in total income over the period concerned. The selected period spans a complete property cycle in the UK of boom, recession and recovery, but whilst decline in the property market had set in by 1990, total income on this set of properties does not fall until 1995 and then only by a small amount. This illustrates the effect of UK lease structures in protecting from both depreciation and market conditions over the short- and medium-term and, hence, it is difficult to draw conclusions about the former from the total income series [4]. Figure 1 further illustrates this effect, displaying in real terms the changes in income against a market rental growth series. It is also interesting to note that the real total income of the sample fails to grow from 1993 onwards.

Figure 1: Total Income from the study sample compared with rental growth: 1984-2003

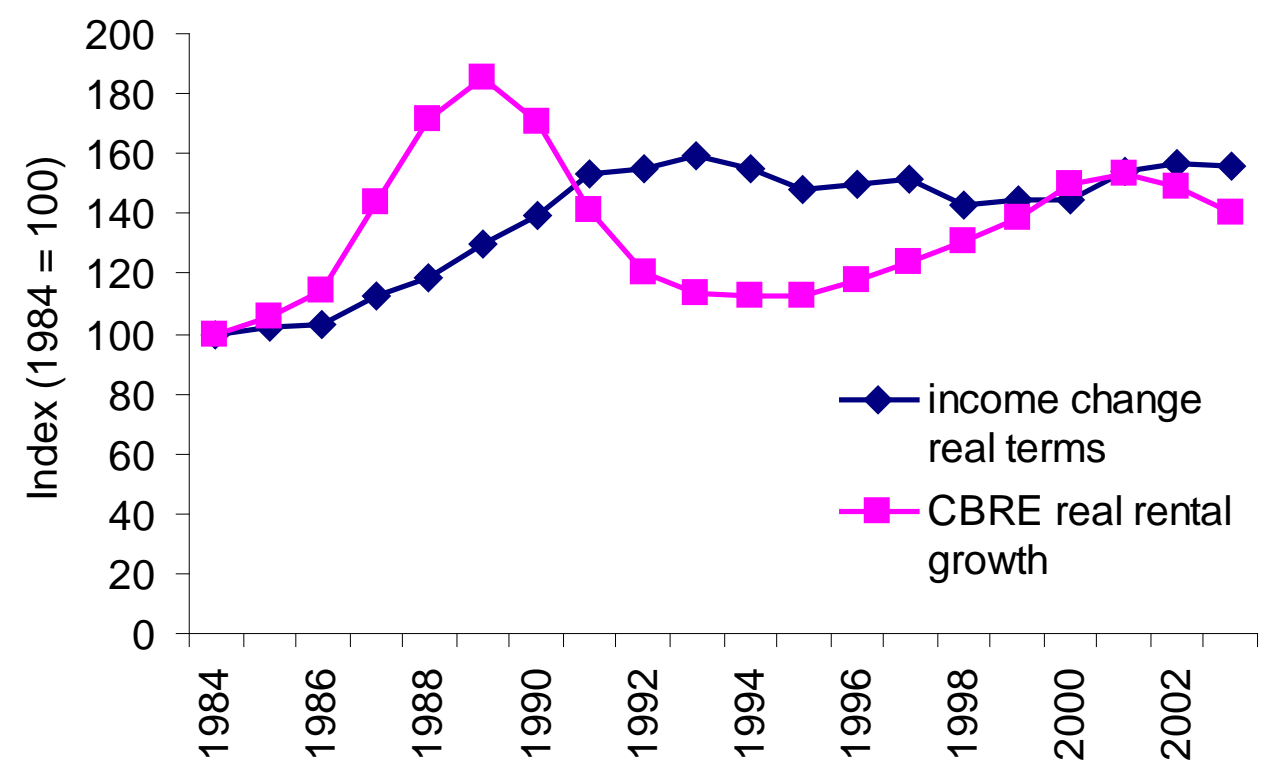

Rental growth series source: CBRE (2006) UK Prime Rent and Yield Monitor 
The analysis also shows the proportions of income taken up by different categories of expenditure. Around $10 \%$ of the gross income in each year was used for revenue expenditure, a proportion that has grown slightly but has generally been stable over the period. In the case of capital expenditure, though, the proportion varies quite significantly between years, with it accounting for around $5 \%$ of gross income in some years, but up to $30 \%$ in 1989 [5]. This means that net cash flow varies considerably around its average level of $80 \%$ of gross income. High levels of gearing could then further exacerbate this net income volatility.

At a sector level, some differences between property types emerge. Table II shows that offices have received the most expenditure out of income and industrial properties the least over the period. The perhaps surprising place of industrials in this ranking is probably related to the type of industrial properties held by institutional investors modern light industrial and warehousing premises rather than factories and sites for heavy industry. Meanwhile, offices have not only required most expenditure, but have also shown the greatest volatility in expenditure and net cash flow. Twice during the period, the net cash flow of the office properties was less than $50 \%$ of their gross income. Yet, despite this higher rate of spending, offices have experienced the highest rates of (post-expenditure) rental depreciation, a result found by IPF (2005a), Baum (1991) and CEM (1999).

Table II - Sample sizes, rental depreciation and net cash flow by property type

\begin{tabular}{lccc}
\hline & Shops & Offices & Industrials \\
\hline Sample & 339 & 165 & 120
\end{tabular}


Rental depreciation

$\%$ p.a.

Net income as a $\%$ of gross income

$\begin{array}{lll}\text { Average } & 92 \% & 90 \%\end{array}$

Net cash flow as a $\%$ of gross income

$\begin{array}{llll}\text { Average } & 81 \% & 75 \% & 86 \%\end{array}$

Minimum reduction $\quad 90 \% \quad 88 \% \quad 95 \%$

$\begin{array}{llll}\text { Maximum reduction } & 67 \% & 42 \% & 66 \%\end{array}$

Depreciation rates source: IPF (2005a).

The sector balance of a UK REIT can, therefore, further influence its distributable income and its exposure to depreciation. However, before concluding that an office REIT will be most severely affected of all, it should be remembered that depreciation may strike property types differently in the future to how it has done in the past.

\section{Conclusions}

This paper has set out to explore issues relating to the effects of depreciation on the income and distributions of a UK REIT. Such considerations are important in assessing how they will perform and whether the UK REIT market is likely to be successful. The rules for UK REITs announced in the Finance Act 2006 appear to give them flexibility in portfolio and, hence, depreciation management. However, depreciation will still affect the returns of such vehicles through its effects on income received and cash flow, the extent of the impact depending on factors such as the size of the vehicle, the properties it holds and the causes of depreciation at any one time. 
Investors in and analysts of UK REITs should be interested in these effects because of the close link between cash flow and distributions in a REIT structure. Their potential impact may be explored through reference to the experience of other vehicles, but in looking to the US for lessons, where REITs have been established for many years, few conclusions can be drawn. This is because of differences in accounting regimes which, for US Equity REITs, can cause net income to be much lower than net cash flow and so allow more discretion in distribution policy. Even if these did not exist, though, structural differences between the two markets may make UK properties more prone to building depreciation, although greater restrictions in land supply may, conversely, support the values of their sites.

Therefore, this paper has also examined income and expenditure on UK properties to see what lessons might be learned. Although the dataset has a number of limitations, these are such that the results are likely to understate rather than overstate the costs of depreciation for a portfolio. The analysis demonstrates the importance of expenditure on properties, hitherto left out of empirical depreciation measurement in the property literature. Capital expenditure, in particular, reduces income available for distribution and could be a source of volatility from year to year, making 'high and stable' cash flow perhaps less stable than investors expect. 


\section{Notes}

[1] Although International Accounting Standards outline both cost and fair value approaches to accounting for property investments (IASC, 2000), the UK government has specifically legislated that UK REITS must use the fair value (i.e. market value) approach (Finance Act 2006, section 107(6)), consistent with previous UK rules for investment property (ICAEW, 1981).

[2] It is, of course, possible for these changes to be positive or negative.

[3] Devaney et al (2007), show average US lease terms in 2002 to be 5.8, 5.0 and 3.6 years for the Retail, Office and Industrial sectors, compared to UK lengths in 2002 of 9.8, 7.6 and 7.3 years respectively (BPF/IPD, 2004). These are equalrather than value-weighted averages as no US value-weighted figures were available to the authors.

[4] There are several analytical difficulties in assessing the effect of depreciation on gross income. It has a different profile to rental values because of issues such as vacancies and lease structures. Rental depreciation rates will not, therefore, feed immediately though into income flows. Meanwhile, it is unclear how an appropriate income growth benchmark could be constructed

[5] These fluctuations show some cyclical relationship, the correlation with year on year changes in rental growth being 0.49 . 


\section{References}

Barras, R. and Clark, P. (1996), "Obsolescence and Performance in the Central London Office Market", Journal of Property Valuation and Investment. Vol. 14 No. 4, pp. 6378.

Baum, A. (1991), Property Investment Depreciation and Obsolescence, Routledge, London.

Baum, A. (1994), "Quality and Property Performance", Journal of Property Valuation and Investment, Vol. 12 No. 1, pp. 31-46.

Baum, A. (1997), Trophy or Tombstone? A Decade of Depreciation in the Central London Office Market, Lambert Smith Hampton and HRES, London.

Baum, A. and Turner, N. (2004), "Retention Rates, Reinvestment and Depreciation in European Office Markets", Journal of Property Investment and Finance, Vol. 22 No. 3, pp. 214-235.

BPF / IPD. (2004), BPF IPD Annual Lease Review, British Property Federation, London.

BPF / IPF / RICS. (2004a). A Guide to Real Estate Investment Trusts - and why we need them. London: British Property Federation / Investment Property Forum / Royal Institution of Chartered Surveyors.

BPF / IPF / RICS. (2004b), Industry Response to HMT \& Inland Revenue Consultation Document, British Property Federation / Investment Property Forum / Royal Institution of Chartered Surveyors, London, July 2004.

Bradley, M., Capozza, D. R. and Seguin, P. J. (1998), "Dividend Policy and Cash-flow Uncertainty", Real Estate Economics, Vol. 26 No. 4, pp. 555-580.

CALUS. (1986), Depreciation of Commercial Property, College of Estate Management, Reading. 
Campbell, R. and Sirmans, C. (2002), "Policy implications of structural options in the development of Real Estate Investment Trusts in Europe: lessons from the American experience", Journal of Property Investment and Finance, Vol. 20 No. 4, pp. 388405.

CBRE. (2006), UK Prime Rent and Yield Monitor, CB Richard Ellis, London.

CEM. (1999), The Dynamics and Measurement of Commercial Property Depreciation in the UK, College of Estate Management, Reading.

Corgel, J. B., McIntosh, W. and Ott, S. H. (1995), "Real Estate Investment Trusts: A Review of the Financial Economics Literature", Journal of Real Estate Literature, Vol. 3 No. 1, pp. 13-43.

Crosby, N., Hughes, C. and Murdoch, S. (2005), Monitoring the 2002 Code of Practice for Commercial Leases, Office of the Deputy Prime Minister, London.

Devaney, S. P., Lee, S. L. and Young, M. S. (2007), "Serial Persistence in Individual Real Estate Returns in the UK", Journal of Property Investment \& Finance, Forthcoming.

HM Treasury (2004), Promoting more flexible investment in property: a consultation, HM Treasury and Inland Revenue, London, March 2004.

HM Treasury (2005), UK Real Estate Investment Trusts: a discussion paper, HM Treasury and Inland Revenue, London, March 2005.

Howe, J. S. and Jain, R. (2004), "The REIT Modernisation act of 1999", Journal of Real Estate Finance and Economics, Vol. 28 No. 4, pp. 369-388.

IASC (2000), International Accounting Standard IAS 40: Investment Property, International Accounting Standards Committee, London. 
ICAEW (1981), Statement of Standard Accounting Practice No 19: Accounting for Investment Properties, Institute of Chartered Accountants in England and Wales, London.

IPF (2005a), Depreciation in Commercial Property Markets, Investment Property Forum / IPF Educational Trust, London.

IPF (2005b), Understanding Commercial Property Investment: A Guide for Financial Advisers, 2005 edition, Investment Property Forum, London.

JLW (1987), Obsolescence: The Financial Impact of Property Performance, Jones Lang Wootton, London.

Kennedy, P., Haddock, M. and Sauer, A. (2004), European capitalisation rates - towards a consistent approach, Paper presented at the PREA conference, Los Angeles, October 2004.

Law, V. (2004), The Definition and Measurement of Rental Depreciation in Investment Property, Unpublished PhD dissertation, University of Reading.

Lizieri, C. (2004), Promoting More Flexible Investment in Property: Response to HM Treasury / Inland Revenue Consultation Paper, July 2004, University of Reading.

Wang, K., Erickson, J. and Gau, G. W. (1993), "Dividend Policies and Dividend Announcement Effects", Journal of the American Real Estate and Urban Economics Association, Vol. 21 No. 2, pp. 185-201.

Worzala, E. and Sirmans, C. F. (2003), "Investing in International Real Estate Stocks: A Review of the Literature", Urban Studies, Vol. 40 Nos. 5-6, pp. 1115-1149.

Yungmann, G. and Taube, D. (2001), "FFO - Earnings or Cash Flow?", Real Estate Portfolio, NAREIT, May/June 2001. 
Appendix 1 - Sector Level Income and Expenditure Results

Table A1 - Income and expenditure for portfolio of shop properties held over the period 1984-2003 (figures in millions)

\begin{tabular}{cccccccc}
\hline \multicolumn{2}{c}{$\begin{array}{c}\text { Total } \\
\text { income }\end{array}$} & $\begin{array}{l}\text { IPD defined } \\
\text { revenue } \\
\text { expenditure }\end{array}$ & $\begin{array}{l}\text { Net } \\
\text { income }\end{array}$ & $\begin{array}{l}\text { as \% of } \\
\text { gross } \\
\text { income }\end{array}$ & $\begin{array}{l}\text { IPD defined } \\
\text { capital } \\
\text { expenditure }\end{array}$ & $\begin{array}{l}\text { Net cash } \\
\text { flow }\end{array}$ & $\begin{array}{l}\text { as \% of } \\
\text { gross } \\
\text { income }\end{array}$ \\
\hline & & & & & & & \\
1984 & 29.2 & 1.5 & 27.7 & $95 \%$ & 3.4 & 24.4 & $83 \%$ \\
1985 & 27.6 & 2.0 & 25.6 & $93 \%$ & 4.0 & 21.6 & $78 \%$ \\
1986 & 28.0 & 1.7 & 26.4 & $94 \%$ & 6.1 & 20.3 & $72 \%$ \\
1987 & 33.4 & 1.9 & 31.5 & $94 \%$ & 4.5 & 27.0 & $81 \%$ \\
1988 & 36.7 & 2.2 & 34.5 & $94 \%$ & 9.2 & 25.3 & $69 \%$ \\
1989 & 46.1 & 3.7 & 42.4 & $92 \%$ & 9.7 & 32.7 & $71 \%$ \\
1990 & 55.2 & 4.0 & 51.2 & $93 \%$ & 3.4 & 47.8 & $87 \%$ \\
1991 & 62.0 & 4.3 & 57.8 & $93 \%$ & 6.8 & 51.0 & $82 \%$ \\
1992 & 66.6 & 5.9 & 60.7 & $91 \%$ & 4.6 & 56.1 & $84 \%$ \\
1993 & 68.3 & 6.2 & 62.0 & $91 \%$ & 0.3 & 61.7 & $90 \%$ \\
1994 & 69.4 & 8.1 & 61.3 & $88 \%$ & 3.6 & 57.7 & $83 \%$ \\
1995 & 70.5 & 8.8 & 61.7 & $88 \%$ & 0.6 & 61.1 & $87 \%$ \\
1996 & 71.5 & 7.2 & 64.3 & $90 \%$ & 1.8 & 62.5 & $87 \%$ \\
1997 & 72.4 & 6.3 & 66.0 & $91 \%$ & 5.6 & 60.5 & $84 \%$ \\
1998 & 76.5 & 6.6 & 69.9 & $91 \%$ & 9.1 & 60.8 & $79 \%$ \\
1999 & 79.4 & 6.3 & 73.1 & $92 \%$ & 6.7 & 66.3 & $84 \%$ \\
2000 & 83.4 & 6.4 & 77.0 & $92 \%$ & 21.3 & 55.7 & $67 \%$ \\
2001 & 88.5 & 7.5 & 81.0 & $92 \%$ & 7.3 & 73.7 & $83 \%$ \\
2002 & 92.1 & 7.8 & 84.3 & $92 \%$ & 10.4 & 73.8 & $80 \%$ \\
2003 & 94.7 & 7.6 & 87.1 & $92 \%$ & 5.1 & 82.0 & $87 \%$ \\
Average & & & & $92 \%$ & & & $81 \%$ \\
\hline
\end{tabular}

Table A2 - Income and expenditure for portfolio of office properties held over the period 1984-2003 (figures in millions)

\begin{tabular}{cccccccc}
\hline & $\begin{array}{l}\text { Total } \\
\text { Yncome }\end{array}$ & $\begin{array}{l}\text { IPD defined } \\
\text { revenue } \\
\text { expenditure }\end{array}$ & $\begin{array}{l}\text { Net } \\
\text { income }\end{array}$ & $\begin{array}{l}\text { as \% of } \\
\text { gross } \\
\text { income }\end{array}$ & $\begin{array}{l}\text { IPD defined } \\
\text { capital } \\
\text { expenditure }\end{array}$ & $\begin{array}{l}\text { Net cash } \\
\text { flow }\end{array}$ & $\begin{array}{l}\text { as \% of } \\
\text { gross } \\
\text { income }\end{array}$ \\
\hline & & & & & & & \\
1984 & 39.0 & 4.2 & 34.8 & $89 \%$ & 7.8 & 27.0 & $69 \%$ \\
1985 & 44.2 & 3.5 & 40.7 & $92 \%$ & 12.1 & 28.6 & $65 \%$ \\
1986 & 46.9 & 3.6 & 43.3 & $92 \%$ & 5.9 & 37.4 & $80 \%$ \\
1987 & 53.7 & 4.0 & 49.6 & $93 \%$ & 8.5 & 41.2 & $77 \%$ \\
1988 & 62.0 & 4.1 & 57.9 & $93 \%$ & 7.5 & 50.4 & $81 \%$ \\
1989 & 72.5 & 4.8 & 67.7 & $93 \%$ & 36.9 & 30.8 & $42 \%$ \\
1990 & 85.0 & 8.2 & 76.8 & $90 \%$ & 9.3 & 67.4 & $79 \%$ \\
1991 & 99.2 & 11.5 & 87.7 & $88 \%$ & 7.4 & 80.2 & $81 \%$
\end{tabular}




$\begin{array}{cccccccc}1992 & 100.3 & 11.7 & 88.7 & 88 \% & 3.6 & 85.1 & 85 \% \\ 1993 & 106.1 & 16.5 & 89.7 & 84 \% & 6.0 & 83.6 & 79 \% \\ 1994 & 104.7 & 12.3 & 92.4 & 88 \% & 10.3 & 82.1 & 78 \% \\ 1995 & 99.4 & 11.8 & 87.6 & 88 \% & 39.4 & 48.3 & 49 \% \\ 1996 & 104.5 & 10.6 & 94.0 & 90 \% & 33.8 & 60.1 & 58 \% \\ 1997 & 107.3 & 12.4 & 94.9 & 88 \% & 3.2 & 91.7 & 85 \% \\ 1998 & 103.7 & 13.4 & 90.3 & 87 \% & 2.3 & 88.0 & 85 \% \\ 1999 & 108.0 & 10.8 & 97.3 & 90 \% & 11.1 & 86.1 & 80 \% \\ 2000 & 109.9 & 10.0 & 99.9 & 91 \% & 8.8 & 91.1 & 83 \% \\ 2001 & 119.1 & 10.2 & 108.9 & 91 \% & 12.2 & 96.7 & 81 \% \\ 2002 & 123.1 & 13.1 & 110.0 & 89 \% & 6.4 & 103.5 & 84 \% \\ 2003 & 129.7 & 13.2 & 116.5 & 90 \% & 2.9 & 113.6 & 88 \% \\ \text { Average } & & & & 90 \% & & & 75 \%\end{array}$

Table A3 - Income and expenditure for portfolio of industrial properties held over the period 1984-2003 (figures in millions)

\begin{tabular}{cccccccc}
\hline Year & $\begin{array}{c}\text { Total } \\
\text { income }\end{array}$ & $\begin{array}{l}\text { IPD defined } \\
\text { revenue } \\
\text { expenditure }\end{array}$ & $\begin{array}{l}\text { Net } \\
\text { income }\end{array}$ & $\begin{array}{l}\text { as \% of } \\
\text { gross } \\
\text { income }\end{array}$ & $\begin{array}{l}\text { IPD defined } \\
\text { capital } \\
\text { expenditure }\end{array}$ & $\begin{array}{l}\text { Net cash } \\
\text { flow }\end{array}$ & $\begin{array}{l}\text { as \% of } \\
\text { gross } \\
\text { income }\end{array}$ \\
\hline 1984 & 23.0 & 1.9 & 21.2 & $92 \%$ & 1.5 & 19.7 & $86 \%$ \\
1985 & 26.6 & 1.5 & 25.1 & $94 \%$ & 1.2 & 24.0 & $90 \%$ \\
1986 & 28.5 & 1.3 & 27.2 & $95 \%$ & 0.2 & 27.0 & $95 \%$ \\
1987 & 30.0 & 1.1 & 29.0 & $96 \%$ & 0.9 & 28.1 & $94 \%$ \\
1988 & 32.8 & 1.5 & 31.3 & $95 \%$ & 2.4 & 28.9 & $88 \%$ \\
1989 & 36.5 & 1.6 & 34.9 & $96 \%$ & 0.8 & 34.1 & $93 \%$ \\
1990 & 41.5 & 1.9 & 39.6 & $96 \%$ & 0.2 & 39.4 & $95 \%$ \\
1991 & 47.5 & 2.7 & 44.8 & $94 \%$ & 1.2 & 43.5 & $92 \%$ \\
1992 & 49.7 & 4.4 & 45.3 & $91 \%$ & 0.0 & 45.2 & $91 \%$ \\
1993 & 52.5 & 3.0 & 49.5 & $94 \%$ & 1.3 & 48.2 & $92 \%$ \\
1994 & 53.3 & 3.1 & 50.2 & $94 \%$ & 15.3 & 34.9 & $66 \%$ \\
1995 & 54.5 & 3.4 & 51.2 & $94 \%$ & 1.1 & 50.1 & $92 \%$ \\
1996 & 56.3 & 4.5 & 51.8 & $92 \%$ & 0.9 & 50.9 & $90 \%$ \\
1997 & 63.2 & 2.7 & 60.5 & $96 \%$ & 4.6 & 55.8 & $88 \%$ \\
1998 & 55.8 & 3.6 & 52.3 & $94 \%$ & 2.7 & 49.6 & $89 \%$ \\
1999 & 55.7 & 4.1 & 51.6 & $93 \%$ & 10.7 & 40.9 & $73 \%$ \\
2000 & 57.1 & 3.4 & 53.7 & $94 \%$ & 3.2 & 50.5 & $88 \%$ \\
2001 & 61.1 & 3.8 & 57.2 & $94 \%$ & 17.0 & 40.2 & $66 \%$ \\
2002 & 65.5 & 5.0 & 60.5 & $92 \%$ & 8.1 & 52.4 & $80 \%$ \\
2003 & 63.2 & 5.1 & 58.2 & $92 \%$ & 9.6 & 48.6 & $77 \%$ \\
Average & & & & $94 \%$ & & & $86 \%$ \\
\hline
\end{tabular}

This article is ( $)$ Emerald Group Publishing and permission has been granted for this version to appear here (http://centaur.reading.ac.uk/). Emerald does not grant permission for this article to be further copied / distributed or hosted elsewhere without the express permission from Emerald Group Publishing Limited. 